\title{
Determine the Elective Courses in Islamic Higher Education Using Transportation Vogel's Approximation Method
}

\author{
Dindin Jamaluddin ${ }^{1}$ Elis Ratna Wulan ${ }^{2, *}$ Agus Maolana Roby ${ }^{3}$ \\ ${ }^{1}$ Islamic Education Department, UIN Sunan Gunung Djati Bandung, Indonesia \\ ${ }^{2,3}$ Mathematics Department, UIN Sunan Gunung Djati Bandung, Indonesia \\ *Corresponding author. Email: elis_ratna_wulan@uinsgd.ac.id
}

\begin{abstract}
The assignment problem is a special case of the linear programming problem in the industrial, business, education, and assignment problems that we often find in everyday life. The assignment problem addresses issues related to the optimal assignment from a variety of productive and different levels of efficiency. This research discusses the assignment problem by using a new method namely the Transportation Vogel's Approximation Method (TVAM). The TVAM Method is a method to solve the assignment problem without having to check the optimality. In general, the TVAM method algorithm is to determine the smallest value of each row or column, allocate the largest penalty so that demand is reduced and the supply has been isolated, then calculate the cost of transportation. From the results of this study, to determine elective courses in Islamic Higher Education with the minimum operational cost is $\$ 81$.
\end{abstract}

Keywords: Assignment Problem, Elective Courses, Islamic Higher Education, Optimal Solution, TVAM.

\section{INTRODUCTION}

Operation research is the utilization of logical strategies to tackle issues that emerge in the execution of exercises so the utilization of assets can be ideal and productive. Ideal outcomes are gotten by utilizing advancement which is important for tasks research $[1,4]$. There are numerous techniques introduced in tasks research that we can use as per the sorts of issues that exist and get ideal outcomes. One of the issues in tasks research is the task issue.

The assignment problem is a central advance towards accomplishing an objective in an arrangement. In finishing some current work, every representative may have various degrees of capability or profitability $[2,6$, $7,8]$. The strategy for tackling the task issue, to get the most ideal arrangement, is by utilizing the TVAM technique. The greatest favourable position of utilizing this technique is that the strategy utilized in taking care of the issue is extremely effective as far as iterative effectiveness $[9,15,16]$. In this exploration, the essayist will take care of the task issue utilizing the TVAM strategy to get the ideal arrangement.

\section{LITERATURE REVIEW}

\subsection{Assignment Problem}

An assignment is a stage to decide an assignment at a specific chance to get ideal outcomes. The issue in the task that will be inspected in this paper is an elective way to deal with take care of the reasonable issue $[5,10,18]$. The executives frequently faces issues identified with ideal task to different sorts of gainful assets or staff who have various degrees of proficiency for various errands $[14,21,22]$.

The assignment problem is a problem that has only one optimization goal, namely maximizing or minimizing a resource (revenue, cost, distance, or time) used to complete the task. The assignment problem is a special case of a linear program that allocates resources to activities on a one-to-one basis. Thus, each resource (employee, machine) has only one task in each activity (job, location, or event). Consequently, there will be a regular $C i j$ corresponding to task $i(i=1,2, \ldots, m)$ doing task $j(j=1,2, \ldots, n)$. Thus, the objective of the assignment problem is to assign each appropriate task to the worker so that the total expenditure of resources 
(income, cost, distance, or time) to complete all tasks can be optimized $[3,20]$. From real numbers as follows:

Table 1. Assignment Matrix

\begin{tabular}{|c|c|c|c|c|c|}
\hline \multirow{2}{*}{ Worker } & \multicolumn{5}{|c|}{ Job } \\
\hline & 1 & 2 & 3 & $\ldots$ & $\mathrm{N}$ \\
\hline 1 & $C_{11}$ & $C_{12}$ & $C_{13}$ & $\cdots$ & $C_{1 n}$ \\
\hline 2 & $C_{12}$ & $C_{22}$ & $C_{23}$ & $\cdots$ & $C_{2 n}$ \\
\hline$\vdots$ & $\vdots$ & $\vdots$ & $\because$ & $\vdots$ & $\vdots$ \\
\hline $\mathbf{N}$ & $C_{n 1}$ & $C_{n 2}$ & $\mathrm{C}_{n 3}$ & $\cdots$ & $C_{n n}$ \\
\hline
\end{tabular}

This assignment model can be expressed mathematically as follows:

$$
x_{i j}=
$$

$\{1, \quad$ if worker $i$ is assigned to job $j$

$\{0, \quad$ if worker $i$ is not assigned to job $j$

or it can also be stated as a linear programming problem as follows $[11,12]$ :

$$
\min Z=\sum_{i=1}^{n} \sum_{j=1}^{n} c_{i j} x_{i j}
$$

subject to:

$$
\begin{gathered}
\sum_{i=1}^{n} x_{i j}=1 ; i=1,2, \ldots, n \text { and } \\
\sum_{j=1}^{n} x_{i j}=1 ; j=1,2, \ldots, n \\
\text { for } x_{i j}=0 \text { or } 1
\end{gathered}
$$

where $C_{i j}$ is a known constant.

\subsection{TVAM Method}

The TVAM (Transportation Vogel's Approximation Method) method is a new method for solving assignment problems. This method can produce optimal solutions directly without having to check the optimality like the Hungarian method [10, 13]. In this method, the TVAM Method algorithm will be explained to solve the assignment problem.

The TVAM method algorithm is as follows:

- Build an assignment matrix, if the matrix is unbalanced, use Dummy to make it a balanced matrix.

- Find the smallest value on each row and then perform the subtraction operation with the smallest value that has been selected in the same row.

- Find the smallest value in each column then perform the subtraction operation with the smallest value that has been selected in the same column.
- Calculate the penalty by Subtracting the smallest element from the next smallest element in each row and column.

- Identify the row or column with the highest penalty, then select the smallest entry of the selected row or column selected and allocate the tasks.

- Reduction of rows and columns to assigned entries.

- Repeat step four.

- Stop when all rows and columns have been reduced.

The TVAM (Transportation Vogel's Approximation Method) method is another technique for taking care of task issues. This strategy can create ideal arrangements straightforwardly without checking the optimality like the Hungarian technique $[17,23]$. In this technique, the TVAM Method calculation will be disclosed to take care of the task issue.

The TVAM method algorithm is as per the following:

- $\quad$ Build a task grid, if the lattice is lopsided, utilize Dummy to make it a decent framework.

- Find the littlest incentive on each line and afterward play out the deduction activity with the littlest worth that has been chosen in a similar column.

- Find the littlest incentive in every segment at that point play out the deduction activity with the littlest worth that has been chosen in a similar segment.

- Calculate the punishment by Subtracting the littlest component from the following littlest component in each line and segment.

- Identify the line or segment with the most noteworthy punishment, at that point select the littlest passage of the chose line or section chose and apportion the errands.

- Reduction of lines and segments to allocated passages. 
- Repeat stage four.

- Stop when all lines and segments have been diminished.

\section{RESULTS AND DISCUSSION}

Integrative curriculum can be applied to catalyze new energy to present a more comprehensive and tolerant atmosphere [24]. The Mathematics Department in the one of Islamic Higher Education has offered five elective courses (jobs), namely 1,2,3,4,5 and five lecturers (workers), namely A, B, C, D, E taking into account the ability of the lecturers. The head of the university estimates the cost of lecturers per elective courses, then determine the assignment of lecturers to the elective courses to minimize the total cost, the cost is in dollars. The table is as follows [19].

Table 2. Data for Assignment Problem using TVAM Method

\begin{tabular}{cccccc}
\hline & \multicolumn{5}{c}{ Elective Course } \\
\cline { 2 - 6 } Lecturer & 1 & 2 & 3 & 4 & 5 \\
\hline A & 20 & 30 & 25 & 15 & 35 \\
B & 25 & 10 & 40 & 12 & 28 \\
C & 15 & 18 & 22 & 32 & 24 \\
D & 29 & 8 & 34 & 10 & 40 \\
E & 35 & 23 & 17 & 26 & 45 \\
\hline
\end{tabular}

After applying the algorithm of the TVAM method, courses in Islamic Higher Education that are represented in Table 3. we get the optimum solution to determine the elective

Table 3. Allocation of Lecturers Using TVAM Method

\begin{tabular}{cccccc} 
& \multicolumn{5}{c}{ Elective Course } \\
\cline { 2 - 6 } Lectureryyyy & 1 & 2 & 3 & 4 & 5 \\
A & 20 & 30 & 25 & 15 & 35 \\
B & 25 & 10 & 40 & 12 & 28 \\
D & 15 & 18 & 22 & 32 & 24 \\
E & 29 & 8 & 34 & 10 & 40 \\
\hline
\end{tabular}

: Assignment allocation

Since all the lecturers have been allocated, the optimal solution has been achieved by the following details:

Lecturer A is assigned to Elective Course 1 for a cost of 20

Lecturer B is assigned to Elective Course 2 for a cost of 10

Lecturer $\mathrm{C}$ is assigned to Elective Course 5 for a cost of 24

Lecturer D is assigned to Elective Course 4 for a cost of 10
Lecturer $\mathrm{E}$ is assigned to Elective Course 3 for a cost of 17

The optimal solution is

$$
\begin{aligned}
Z= & \sum_{i=1}^{n} \sum_{j=1}^{n} c_{i j} x_{i j} \\
& =\sum_{i=1}^{5} \sum_{j=1}^{5} c_{i j} x_{i j} \\
= & 81
\end{aligned}
$$

Thus, the total cost to be incurred if Islamic Higher Education will offer five elective courses is $\$ 81$. 


\section{CONCLUSION}

From the research results, the TVAM (Transportation Vogel's Approximation Method) method is a new method for solving an assignment problem that aims to get the optimal solution. The way to get the optimal solution is to determine the smallest value for each row and column then perform the subtraction operation with the smallest value that has been selected in the same row and column. Further, calculate the penalty by subtracting the smallest element from the next smallest element in each row and column, Identify the row or column with the largest penalty, then select the smallest entry from the selected row or selected column then allocate tasks, reduce rows and columns to the entries that have been assigned, repeat step two until all rows and columns have been reduced. In the minimization case in determining elective courses assignment problem in Islamic Higher Education after using the TVAM method on a $5 \times 5$ matrix, the total cost to be incurred by the Islamic Higher Education is \$ 81. By allocation: Lecturer A is assigned to Elective Courses 1 at cost 20, Lecturer B is assigned to Elective Courses 2 at cost 10, Lecturer $C$ is assigned to Elective Courses 5 at cost 24, Lecturer D is assigned to Elective Courses 4 at cost 10, and Lecturer E is assigned to Elective Courses 3 for 17 . For the next research, the authors will for a matrix size greater than $5 \times 5$ and add the problem of unbalanced assignment. This method will guide the decision making process in Islamic Higher Education with a simple and efficient way.

\section{AUTHORS' CONTRIBUTIONS}

The first author contribution as literature reviewer. Meanwhile, the second author contribution as data analyst. The last, the third author contribution as data collector

\section{ACKNOWLEDGMENTS}

This acknowledgements was conveyed to Rector and staff who have supported this research.

\section{REFERENCES}

[1] Sudrajat, Pendahuluan Penelitian Operasional Bandung: Padjadjaran University Lecturer Notes, 2008.

[2] H A Taha, Riset Operasi Jakarta: Gramedia pp $230-240,1996$.

[3] S Pangestu, M Asri, and T H Handoko, Dasardasar Operations Research $2^{\text {nd }}$ Edition New York: McGraw-Hill Publishing Company pp $89-97,2000$.

[4] S Prawirosentono, Riset Operasi dan Ekonofisika Jakarta: Bumi Aksara p 115, 2005.

[5] H D Lieberman, Introduction Operations Research Volume 3 Yogyakarta: ANDI Copyright pp $65-72,2005$.
[6] J Supranto, Riset Operasi untuk Pengambilan Keputusan, Jakarta: Salemba Empat, p 67, 1988.

[7] W L Winston, Operation Research Applications and Algoritms $4^{\text {th }}$ Edition, New York: Duxbury p 30, 2004.

[8] J D S H Hilir, Pengantar Riset Operasi $5^{\text {th }}$ Edition, Jakarta: Erlangga pp 112 - 114, 1994.

[9] T Dimyati and D Ahamad, Operations Research Model-Model Pengambilan Keputusan, Bandung: Sinar Baru Algensido p 49, 2002.

[10] J J Siang, Riset Operasi dalam Pendekatan Algoritma $2^{\text {nd }}$ Edition, Yogyakarta: CV Andi Offset pp $25-35,2014$.

[11] L D G and $Y$ Y, Linear and Nonlinear Programming, New York: Springer pp 145, 2008.

[12] Soekatiwi, Linier Programming Teori dan Aplikasinya Khususnya dalam Bidang Pertanian, Jakarta: PT Raja Grafindo Persada pp 90, 1992.

[13] E G Talbi, Metaheuristic: From Design to Implementation Hoboken: John Wiley \& Sons pp $65-71,2009$.

[14] S Pangestu, M Asri, and T H Handoko, Dasar Dasar Operations Research $2^{\text {nd }}$ Edition, Bulaksumur: BPFE pp 14 - 15, 1983.

[15] F S Hillier and G J Lieberman, Introduction to Operations Research $7^{\text {th }}$ Edition, America: McGraw-Hill Higher Education pp 75 - 90, 2011.

[16] T T Dimyati and A Dimyati, Operations Research Model-Model Pengambilan Keputusan, Bandung: Sinar Baru Algensindo p 99, 2002.

[17] H. Kuhn, The Hungarian Method for the Assignment Problem Naval Research Logistic Quarterly II, 1995.

[18] T Dimyati, Tjutju and Dimyati, Operations Research Model-Model Pengambilan Keputusan Bandung: Sinar Baru Algensindo pp $20-21,2003$.

[19] A Thiruppathi and D Iranian, An Innovative Method for Finding Optimal Solution to Assignment Problems, Int. J. Innov. Res. Sci. Eng. Technol. 4(8), 2015.

[20] S K Amponsah, et. al., Proposed Heuristic Method For Solving Assignment Problems Am. J. Operations Reasearch 6, 2016.

[21] N Kardam and Prof. R B, Finding an Optimal Solution of an Assignment Problem by Improved Zero Suffix Method, Int. J. Innov. Res. Sci. Eng. Technol. 7 (7), 2019.

[22] D A Humayra and A H Mohammad, Divide Column and Subtract One Assignment Method for Solving Assignment Problem, American Scientific Research Journal for Engineering Technology and Sciences (ASRJETS) 32 (1), 2017.

[23] S Basriati and L Ayu, Penyelesaian Masalah Penugasan Menggunakan Metode Hungarian 
dan Penalti Jurnal Sains Matematika dan Statistika III, 2017.

[24] S. Suhendi, W.A.F Sawahel, and K.Y. Abdillah, Preventing Radicalism through Integrative Curriculum at Higher Education, Jurnal Pendidikan Islam, Vol. 6 No 1, 2020, pp. 79 - 94. DOI:10.15575/jpi.v6i1.8498 